\title{
Ngeloop Haga Puasa: Social and Cultural Practices to Welcoming Ramadan for Strengthening Muslim Identity
}

\author{
Napsiah Napsiah \\ Department of Sociology, Faculty of Social Sciences and Humanities, \\ Sunan Kalijaga State Islamic University of Yogyakarta, 55281, Yogyakarta, Indonesia \\ Corresponding Author: napsiah@uin-suka.ac.id
}

\section{ARTICLE INFO}

\section{Publication Info:}

Research Article

How to cite:

Napsiah, N. (2020). Ngeloop Haga

Puasa: Social and Cultural

Practices to Welcoming Ramadan for Strengthening Muslim Identity. Society, 8(1), 37-47.

DOI : 10.33019/society.v8i1.131

Copyright $@$ 2020. Owned by Author(s), published by Society

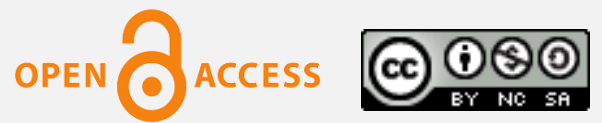

This is an open-access article.

\section{License: Attribution-}

NonCommercial-ShareAlike (CC BY-NC-SA)

Received: December 5, 2019; Accepted: March 1, 2020; Published: March 24, 2020;

\begin{abstract}
The practice of "Ngeloop" (bathing and soaking in seawater) when welcoming Ramadan fasting is a tradition of the South Lampung ethnic group. But in practice, this tradition is not only carried out by the South Lampung ethnic group, but also other ethnic groups that are Muslim. This research aims to determine the actions of Muslims in Lampung in carrying out the local tradition of "Ngeloop Haga Puasa". This research was a descriptive qualitative research with interview and observation methods. The informants were selected using the purposive sampling and snowball sampling technique. The location of the research was conducted in Kalianda, South Lampung District, Lampung Province, Indonesia. The results of the research concluded that the religious value which obliges Muslims to practice fasting has been internalized which is expressed in the form of the practice of ngeloop. Expression in the form of local cultural practices is a strengthening of Muslim identity in South Lampung.
\end{abstract}
Keywords: Fasting; Identity; Lampung; Muslim; Ngeloop; Ramadan

Copyright (C) 2020. Owned by Author(s), published by Society. This is an open-access article under the CC-BY-NC-SA license. 


\section{Introduction}

Local cultural practices such as traditional ceremonies are often used by communities to express gratitude to God for the blessings of health and prosperity (Humaeni, 2016), the opportunity to meet again the Muslim holidays such as welcoming the holy month of Ramadan (Astuti, 2017; Faelasofa, 2011; Herdiyanti \& Cholillah, 2017; Mahfud, 2018; Marzuki, 2014; Nuha, 2016; Riyadi, 2017) which is expressed in various ways.

Reported by Anjaeni (2019), there is local culture to welcome the holy month of Ramadan at the international level, such as in Lebanon, United Arab Emirates, Pakistan, India, Morocco, and Albania, which are described as 3 of them as follows: 1) Lebanon, cannon fire is a tradition that is carried out every Ramadan. One cannon shot is a warning that it's time to break the fast. Whereas two shots were a sign that the fasting month was over and residents were preparing to welcome Eid al-Fitr. 2) India, especially in Delhi, residents come to the alleys and streets in Old Delhi to the Jama mosque, which is the largest mosque in India that can accommodate 25 thousand people. They enjoyed being together in the mosque, which when Ramadan came in the summer, the wide and open courtyard of the mosque remained warm throughout the night. However, during winter, residents spread cloths on tiles and sat together to enjoy dishes brought from their respective homes. 3) Morocco, the residents appoint a "Nafar", who is a volunteer to wake the people to suhoor by playing trumpet musical instruments and calling the name of the head of the family when passing through the houses of residents.

In Iraq, there is a traditional game called "Mheibes" which involves around 40 to 250 players. In the game, a leader will give a ring to someone in a secret way, so that those who receive the ring must submit to the leader's orders. The game only exists when welcoming the month of Ramadan (Yasinta, 2018). While in Egypt, to welcome Ramadan, the traditional lanterns of Ramadan, also known as "Fanoos", are used as decorations that are hung on the walls of homes and workplaces and played by children (Nursalikah, 2018).

In Indonesia, where the majority of the population adheres to Islam, there is also a tradition of welcoming the holy month of Ramadan, as in Java, there is a tradition called "Nyadran", which is to clean graves. This means that those who have died will be cleansed of their sins in the holy month of Ramadan (Riyadi, 2017). In Padang, people bathe using lime water, hoping they will be cleansed of sin and ready to fast Ramadan. This tradition is called "Mandi Balimau" which has been run for generations (Iballa, 2016). In the Bangka district, the tradition of bathing using lime water is called "Mandi Belimau", which has shifted due to changes in the mindset of the community (Herdiyanti \& Cholillah, 2017).

In Tulungagung, "slametan megengan" takes place around the last ten days in Sha'ban month. It is a tradition and ritual to ask God for physical and spiritual strength in fasting during the month of Ramadan and to pray for ancestors who have died. This tradition has been carried out hereditary until now (Aibak, 2010). The local traditions have been widely known by the community so that these traditions become the commodification of tourism.

The community in South Lampung district consists of multi-ethnic and religious groups. They live side by side and maintain togetherness (Sihaloho, 2019). There is a similar tradition in South Lampung, a multi-ethnic population, which has been carried out from generation to generation to welcome the holy month of Ramadan. This tradition is called "Ngeloop" (bathing and soaking in seawater). Although this tradition originates from South Lampung, the practice of "Ngeloop" is also carried out by Muslims from various ethnic groups in South Lampung. This is interesting because other Muslim ethnic groups are part of the practice. The practice of "Ngeloop" has become the practice of Muslims from various ethnic groups who live in South Lampung and around the area.

Copyright (C) 2020. Owned by Author(s), published by Society. This is an open-access article under the CC-BY-NC-SA license. https://doi.org/10.33019/society.v8i1.131 


\section{Ngeloop Haga Puasa: \\ Social Cultural Practices to Welcoming Ramadan for Strengthening Muslim Identity}

Unfortunately, this tradition has not been studied scientifically. The local tradition is local wisdom that enriches the treasury of Indonesian culture. Moreover, in Lampung, which has a multi-ethnic population, the existence of these local traditions is a means to unite Muslims from different ethnicities. Although from different ethnic groups, they also take part in local traditions in South Lampung. This tradition is beneficial for Muslims in South Lampung to strengthen their identity.

Tradition is often extinct because people do not preserve it, arguing that local culture is considered traditional. But in South Lampung, local culture is still carried out, whereas, from its geographical location, the distance is very close to the city of Jakarta, the capital of Indonesia, only separated by the Java Sea, which has potential for modern cultural values, will quickly erase and replace a local culture that is often considered traditional. Until now, the local culture is still preserved by Muslims in South Lampung. The local tradition is the identity of the Muslim community in South Lampung. As such, this research focuses on why do people in South Lampung carry on the tradition of "Ngeloop" (bathing and soaking in seawater) in welcoming the holy month of Ramadan?

\section{Literature Review}

The traditions that develop in society do not come spontaneously but gradually. That stage according to Berger \& Luckmann (1990), in social construction consists of the stages of objectivation, internalization, and expression. This expression stage is the stage that can be seen and can be felt. If the tradition of "Ngeloop" is carried out by the people on the beach/sea, then at the cultural level, the form of expression is visible to many people.

In detail, Berger \& Luckmann (1990) explained the process of accepting social reality into three processes, including 1) Externalization: the continuous outpouring of human selfhood in the world, both in physical and mental activities. As social beings, humans will not remain in themselves but must always express themselves in their activities in the community. This activity is called externalization. 2) Objectivation: can occur when the product of the activity has formed a fact that is external and different from the producers themselves. Although culture originates and is rooted in human subjective awareness, its existence is outside of individual subjectivity. In other words, culture has objective reality and applies to it the objective categories. 3) Internalization: the re-absorption of reality by humans and transforming it once again from the structure of the objective world into the structure of subjective consciousness. Through externalization, society is a human product. Through objectivation, humans become sui generis realities, unique, and with internalization, human beings are the product of society. Through cultural externalization is a human product; through human internalization is a product of a culture.

Tradition and religion are two inseparable things (Setiyawan, 2012). Traditions carried out in the community are often an implementation of the teachings of the religion they believe in. Therefore, the religion which contains truth values is believed by its adherents to be run with a variety, this is what is called Islam Nusantara. The implementation of this truth is very relative because it depends very much on the culture of the local community. That is why the practice of religion often becomes diverse and becomes a characteristic of each community (Astuti, 2017). Even Mahfud (2018) said that local culture is a product of religion. Even though there is a culture in religion, religion, which is universal, will not lose its purity which includes religious law, beliefs, and monotheism (Astuti, 2017), but instead strengthens their identity of the religion they believe in. Ethnic identity can be known from local traditions as forming identity (Callister

Copyright ( ) 2020. Owned by Author(s), published by Society. This is an open-access article under the CC-BY-NC-SA license. 


\section{Ngeloop Haga Puasa: \\ Social Cultural Practices to Welcoming Ramadan for Strengthening Muslim Identity}

et al., 2009). According to Barker (2013), the formation of identity through a process that is socialized and accepted by the community by being implemented in a hereditary way.

\section{Research Methodology}

This research is a qualitative descriptive research to uncover the reasons for the South Lampung ethnic group to carry out this tradition. Data collection in this research used interview techniques. Informants were selected using a purposive sampling technique, by selecting people who are considered to know, be involved, and understand information related to research topics and problems (Patton, 1990). The informants are divided into two categories which are those that have a close relationship with the community so that they have information about local cultural practices. Informants included in this group included 1) Formal figures, consisting of the head of the sub-district, the head of the tourism office, the head of the village, the head of the hamlet, and the head of the neighborhood. 2) Informal figures, consisting of religious figures and traditional leaders. Based on the appointment method, the selection of informants is carried out based on 2 (two) groups of informants above. The selection of informants was carried out using snowball sampling techniques (Groenewald, 2004) to find out in detail the motivation of Muslims in South Lampung to practice local culture.

Also, this research uses non-participant observation techniques intending to explore data that cannot be revealed at the interview. Secondary data was used to complement the data needed in this research, obtained from the urban village office, traditional leaders' notes, previous research, newspapers, magazines, journals, and local newspapers.

The data analysis process begins with data collection, both primary and secondary data. Primary data collection was obtained through interviews with informants and then made the transcript of the results of the interview. Then the observational information was used to triangulate the interview results. Secondary data obtained from village office reports are supporting sources that strengthen primary data. Analysis of qualitative data is carried out by following a model developed by Huberman \& Miles (1984) in Denzin \& Lincoln (1994), known as interaction. This model begins with data collection, data reduction, presentation of data that has been analyzed and drawing conclusions.

The location of the research was conducted in Kalianda, South Lampung District, Lampung Province, Indonesia, which carried out the tradition of "Ngeloop" (bathing and soaking in seawater) to welcome fasting in Ramadan hereditary. Specifically, the location of this research is Canti Beach.

\section{Results and Discussion}

1) Results

\section{A. Muslims in South Lampung}

Lampung Province is the southernmost province in Sumatra. The capital of Lampung province is Bandar Lampung. Lampung Province is inhabited by around 1,269,262 people consisting of various ethnic groups. It is known that the multi-ethnic population resides hereditary. The ethnicity of people living in South Lampung are as follows: Javanese with a percentage of $61.88 \%$ of the total population of Lampung, while ethnic Lampung with a percentage of $11.92 \%$, followed by Sundanese-Banten ethnic with a percentage of $11.27 \%$, Semendo (Sumatra South) with a percentage of $3.55 \%$, and other ethnic groups such as Minangkabau, Bali, Batak, and others with a percentage of $11.35 \%$ (Utami \& Astuti, 2014).

Although the inhabitants of South Lampung have lived for at least three generations, their settlements have not yet fully integrated with the local population. The Balinese settled in the 
location provided by the government because the Balinese were migrated to Lampung in 1963 with the location of Balinuraga village. The Lampung ethnic group is in the village of Agom. Even though the two ethnic groups' settlements are separate, they have togetherness, for example in utilizing public facilities, such as markets and public transportation, so that the relations between the two ethnic groups are still going well (Napsiah et al., 2019).

For migrant Muslim ethnic groups, the relationship between the two went well because besides being together in using public facilities such as markets and public transportation; residents were also united in terms of religious activities. Residents carry out religious social activities in the mosque to perform the five daily prayers and in the open field to perform the Eid Al-Fitr and Eid al-Adha prayers. Religious activities are also often carried out at the nearest sea to welcome the holy month of Ramadan.

\section{B. The Process of Islamization in Lampung}

In general, Islam enters Indonesia in a peaceful manner, which is following the values that will be conveyed to encourage people to do well (God's command) and avoid God's prohibition. Likewise, Islam entered Lampung in a peaceful manner, which was spread throughout Lampung using several methods. Syahputra (2017) suggested this method through:

1) Culture. Walisongo, who peacefully spread religion, did not curb the local culture that was once characterized by Hindu-Buddhist culture, and then was modified into a culture that was nuanced by Islam. Thus, the Islamization process is carried out on the local culture before the people. This means culture becomes the medium of Islamic da'wah itself. The Islamization process in Lampung also uses local cultural media. The Islamization process in Lampung also uses local cultural media. Islam which is implanted through this culture will provide the remaining space for the old religious heritage and existing beliefs, which developed in the community at that time, to be preserved.

2) Trading. The spread of Islam in Lampung was also carried out through trade such as in the coastal areas of North Sumatra which had become the anchorage of Muslim merchant ships that lifted their merchandise from Gujarat, precisely in North Sumatra. Besides trading, Muslim merchants also spread Islam. Islamization through trade was very beneficial because kings and nobles participated in trade activities. Islamic traders from Arab and Gujarat also Javanese located in Malacca brought Islam to the port cities of the north coast of Java. At the same time, the triumph of the Majapahit kingdom fell; this affected the development of Islam in Lampung.

3) Marriage. Muslim merchants have a better life than indigenous people. This makes the interest of indigenous people to establish relationships with Muslim merchants, especially daughters from the nobility.

\section{Piil Pesenggiri: The Philosophy of Ethnic Lampung}

The Lampung ethnic group has a philosophy of life, known as "Piil Pesenggiri" (Irianto \& Margatha, 2011; Napsiah et al., 2019; Sinaga, 2014). In detail, Piil pesenggiri contains the following matters:

1) Juluk-Adek, which means having a traditional title given at a traditional ceremony in marriage. Usually, the titles given to men are Pengiran, Dalom, Batin, Temunggung, Radin, Minak, dan Kimas. Whereas for women are Ratu, Idoman, Pujian, Pimpinan, dan Tuan Ratu. The title given is used in daily life as a form of honor.

2) Nemui-Nyimah, which means being sincere in accepting guests. Guests are people outside the family. This meaning can also be interpreted as caring for others because, in that 


\section{Ngeloop Haga Puasa: \\ Social Cultural Practices to Welcoming Ramadan for Strengthening Muslim Identity}

philosophy, there is meaning when receiving guests, should be given proper food and drink.

3) Nengah-Nyappur. Nyappur is derived from the noun cappur being the verb nyappur which means to integrate. It can be interpreted as a sociable, friendly, and tolerant attitude among people. Nengah-nyappur shows that the character of the Lampung ethnic group socializes without favoritism, without discriminating against individual backgrounds, religion, ethnicity, and culture.

4) Sakai-Sambaiyan. Sakai-Sambaiyan means help and cooperation, which means understanding the meaning of togetherness or cooperation. Sakai-Sambayan is essentially showing a sense of participation and high solidarity with various personal and social activities in general.

The life philosophy of the Lampung ethnic group is implemented in daily life. They did not discriminate among ethnic groups; even cooperating with other ethnic groups became the main goal. Therefore, this philosophy of life is used as a basis for the association of daily life. The values contained in this philosophy are to unite inter-ethnic groups in Lampung.

\section{Islam, Customs, and Traditions in the Lampung Community}

The interaction of Islam and local culture in Lampung is an effort to see the dynamic relationship between Islam and various values and concepts of life that are maintained and inherited and are seen as a way of life by the people of Lampung. The way of life also includes traditions inherited from generation to generation that are still being carried out. In the Lampung tradition, religious values are implemented in a variety of Lampung traditional practices, ranging from having a family, having children, and about death. For example, in traditional marriages in indigenous communities in South Lampung, it is known as "Ngarak Maju". Ngarak, according to the term, means "parade", while Maju means "marriage" So "Ngarak Maju" means the tradition of the Lampung bridal parade carried out at the groom's place, as a sign that a man has officially married a woman. In the tradition of "Ngarak Maju", there is an element of Islamic culture consisting of the use of a tambourine as a musical instrument to accompany the parade of dhikr (Syahputra, 2017).

The tradition of "Manjau Pedom" is a tradition of visiting and staying at a woman's house by the family of a man, which is carried out after the procession of "ijab kabul" (akad nikah or marriage contract). This is to strengthen relationships and help each other between married families (recommended by Islam).

Marhabanan is an activity to thank God for the birth of a child and give a name to the child. The activity is carried out religiously by reading the Book of Barzanji and accompanied by prayer so that children grow into good children and have faith. Barzanji readings are carried out by men led by a religious leader.

Yasinan is a tradition of reciting Surah Yasin together to pray for those who have passed away. Usually "Yasinan" is done on the first, third, seventh, fortieth day, hundredth day and even the thousandth day of the death of a person.

\section{E. Kuruk Puasa (Welcoming Ramadan Fasting)}

Muslims in Kalianda, South Lampung, are the same as Muslims in Indonesia, who believe that the month of Ramadan is the holy month. Ramadan is a month full of forgiveness of sins. As Muslims, the month of Ramadan is believed to be a month full of blessings. Therefore, Muslims are thankful to Allah for giving them health and long life and being able to meet again with the month of Ramadan, the month they are waiting for. 
Lampung people realize that not everyone can meet again with the month of Ramadan because they are no longer given a long life. Some people are unable to carry out Ramadan fasting due to illness. Therefore, the month of Ramadan is a month that is considered a special month. Therefore, happiness to welcome the month of Ramadan is carried out with various preparations, both mental and spiritual.

Muslims in South Lampung prepare themselves to welcome the month of Ramadan starting from basic needs such as clothing and food needs. Therefore, usually, they will shorten working hours outside the home and focus on family matters. The first thing to do is a pilgrimage to the grave which began in the morning. They pray for families who have died.

\section{F. Ngeloop di Lawok (Bathing and Soaking in Seawater): Annual Traditions of Muslims in South Lampung}

Muslims in South Lampung have a tradition before carrying out fasting in the month of Ramadan. They try to strengthen their mental and spiritual by bathing and soaking in the seawater (ngeloop) together. There is no specific choice regarding the beach/sea that will be used as a place to carry out that tradition. The consideration for them is the beach/sea that they can reach and are considered safe to carry out the tradition. The distance between the house and the beach sea is a major consideration in carrying out the tradition of bathing and bathing in seawater. The tradition is carried out on the beach/sea close to where they live.

There are no written records to find out when it was the first time the tradition of "ngeloop" was practiced by Muslims in Kalianda, South Lampung. The people only follow the tradition that has been carried down from one generation to the next generation. In customary practices, there is also no change in implementation.

Literally, "ngeloop haga puasa" means bathing and soaking in seawater to welcome the fasting month of Ramadan. The process is carried out to cleanse them before fasting. Even though they intend to clean themselves, there are no special toiletries or fragrances when bathing and soaking in seawater. There is also no agreed-upon rules for how long to bathe and soak in seawater. According to the informant, the average length of bathing and soaking in seawater ranged from 1 to 2 hours, as revealed by the informant below:
"Bathing and soaking in seawater we do as much as possible. It could be 1 hour or even more. But on average only 2 hours because it was almost night" (Interview with the informant).

Although there is no stipulation about the length of time for bathing and soaking in seawater, according to a mutual agreement, it only ranges from 1 to 2 hours, which is conducted before the Asr Prayer and ends before entering the Maghrib Prayer. Asr prayers are held in the congregation on the beach. The tradition of "ngeloop" is carried out after Asr prayer.

After carrying out the tradition of "ngeloop", visitors carry out "banjakan" or eating together, by spreading the mat and then eating together by way of an elongated or circular line. After the Maghrib prayer time, they will say goodbye to fellow visitors to greet and say goodbye, and also ask to be prayed for to be able to meet again in the month of Ramadan next year and always be given health and strength to carry out fasting during Ramadan.

\section{2) Discussions}

Religious values play an important role in reviving local culture. Living religious values has become a habit in people's lives. Therefore, local culture and religion are both interconnected. 


\section{Ngeloop Haga Puasa: \\ Social Cultural Practices to Welcoming Ramadan for Strengthening Muslim Identity}

However, Mahfud (2018) said that although religion and culture have a close relationship, religion is not a product of local culture because religion comes from God. When humans practice religious teachings, religion becomes the reality of society, so religious values will vary because customs and culture are very diverse. Therefore, in practice, religion also becomes diverse in its implementation. Social and religious practices become the implementation of culture.

The tradition of "ngeloop" is the cultural practice of Muslims in South Lampung to welcoming the month of Ramadan. Local cultural practices are carried out to implement religious values that require adherents to obey and carry out fasting in Ramadan. In this context, Berger \& Luckmann (2019) revealed that the process was an internalization process. The process of internalization is the process of absorbing religious values into each individual who becomes a habit.

Local culture is culture obtained from the community itself which is usually done to show the identity of the community. The identity can be in the form of religious social practices. According to Marzuki (2014), local culture is often synonymous with traditional culture, which is often eroded by modern culture because it is not supported by government policies. In South Lampung, local culture is still maintained. Lampung has a multi-ethnic population. However, all remain committed to carrying out the tradition. Even local governments provide full support for the implementation of local traditions by providing security and comfort in carrying out the tradition of "ngeloop".

Berger \& Luckmann (1990) said that local cultural practices were not automatically done but through several stages. The objectivation stage is the stage where someone is introduced to the values that are adhered to. In this context, Muslims who live in South Lampung are socialized with the Islamic values that they have been following. The teaching value to carry out God's commands and stay away from God's prohibitions has become an inseparable part of their lives. Fasting during the month of Ramadan, for one month, is an obligation for Muslims. Except for those who have been determined by God not to fast in the month of Ramadan like an old person, and are sick. However, both have the obligation to pay fidyah (religious fines/donations).

The second process according to Berger \& Luckmann (1990) in social construction is internalization. Internalization is the value that becomes a personal responsibility, which is done to improve themselves, both with fellow human beings and also with God who created them. This value is grateful because they already have the pleasure in the form of health so that they can carry out fasting in Ramadan every year. The form has become an inseparable part so that it has been internalized in each soul.

In this connection, the tradition of "ngeloop" is a form of expression carried out by the Lampung ethnic group. The expression is carried out annually together with other ethnic groups. Togetherness with other Muslim ethnic groups is very relevant to the values of the philosophy of Lampung including Julek Adek, Napai-Nyimah, Nengah-Nyappur, and SakaiSambaiyan. The philosophical value is used as a value to accept other Muslim ethnic groups to carry out the tradition of "ngeloop". In this context, according to Mahfud (2018), local traditions in which there are local values are forms of community expression in carrying out religious teachings, which become the identity of the ethnic group.

The tradition fo "ngeloop" is the result of an agreement by Muslims in South Lampung, which has been socialized and accepted as an effort to welcome the month of Ramadan and is carried out together, and has the support of various parties, both the government and

Copyright (C) 2020. Owned by Author(s), published by Society. This is an open-access article under the CC-BY-NC-SA license. 
traditional leaders. This is a strengthening of people's identity as Muslims. This tradition, according to Callister et al., (2009) is the identity of the ethnic group.

\section{Conclusions}

Various ways have been done by the community in expressing themselves to practice religious teachings, especially in welcoming the month of Ramadan. Local culture is often a way to express religious teachings that have been accepted for truth and have been internalized to their adherents. Religious values still have universal values in the form of belief in the truth of religious teachings, although various local cultures are used by the community to carry out religious values. "Ngeloop" is a local cultural practice that is an expression of the internalization of religious values that are believed to be true, thus strengthening their identity as Muslims in South Lampung.

\section{Acknowledgment}

The author would like to thank the Institute for Research and Community Services at the Sunan Kalijaga State Islamic University of Yogyakarta for funding support and facilities for making this research successful through the National Applied Research Grant Scheme (Skema Hibah Penelitian Terapan Nasional), Rector's Decree Number 106.12, 2019. The author also wishes to thank all the informants who provided information during this research conducted.

\section{References}

Aibak, K. (2010). Fenomena Tradisi Megengan di Tulungagung. Millah: Jurnal Studi Agama, 10(1), 69-86. https:// doi.org/10.20885/millah.vol10.iss1.art5

Anjaeni, R. W. M. (2019, 5 6). 6 Tradisi Unik Sambut Ramadan dari Penjuru Dunia. Retrieved from liputan6.com: https://www.liputan6.com/citizen6/read/3956684/6-tradisi-unik-sambutramadan-dari-penjuru-dunia

Astuti, H. J. P. (2017). Islam Nusantara: Sebuah Argumentasi Beragama dalam Bingkai Kultural. INJECT (Interdisciplinary Journal of Communication), 2(1), 27-52. https:/ / doi.org/10.18326/inject.v2i1.27-52

Barker, Chris. 2013. Cultural Studies, Teori dan Praktik. (Nurhadi, Trans.) Yogyakarta: Kreasi Wacana.

Berger, P. L., \& Luckmann, T. (1990). Tafsir Sosial atas Kenyataan: Risalah tentang Sosiologi Pengetahuan. (H. Basri, Trans.) Jakarta: LP3ES.

Callister, P., Didham, R., \& Kivi, A. (2009). Who are we? The conceptualisation and expression of ethnicity. Wellington: Statistics New Zealand. Retrieved from http://archive.stats.govt.nz/ /media/Statistics/about-us/statisphere/Files/officialstatistics-research-series/osr-series-v4-2009-conceptualisation-expression-of-ethnicity.pdf

Faelasofa, D. (2011). Ajaran Sunan Geseng Bagi Kehidupan Keagamaan Masyarakat. Komunitas: International Journal of Indonesian Society and Culture, 3(2), 159-168. https:// doi.org/10.15294/komunitas.v3i2.2312

Groenewald, T. (2004). A phenomenological research design illustrated. International journal of qualitative methods, 3(1), 42-55. https:/ / doi.org/10.1177/160940690400300104

Herdiyanti, H., \& Cholillah, J. (2017). Pergeseran Modal Sosial dalam Pelaksanaan Upacara Adat Mandi Belimau Di Dusun Limbung Desa Jada Bahrin Kecamatan Merawang Kabupaten Bangka. Society, 5(2), 1-15. https://doi.org/10.33019/society.v5i2.51 
Huberman, A. M., \& Miles, M. B. (1994). Data management and analysis methods. In N. K. Denzin \& Y. S. Lincoln (Eds.), Handbook of qualitative research (p. 428-444). Sage Publications, Inc.

Humaeni, A. (2016). Ritual, kepercayaan lokal dan identitas budaya masyarakat Ciomas Banten. el Harakah: Jurnal Budaya Islam, 17(2), 157-181. https:/ / doi.org/10.18860/el.v17i2.3343

Iballa, D. K. M. (2016). Tradisi Mandi Balimau di Masyarakat Kuntu: Living Hadis Sebagai Bukti Sejarah. Jurnal Living Hadis, 1(2), 275-293. https:// doi.org/10.14421/livinghadis.2016.1122

Irianto, S., \& Margaretha, R. (2013). Piil pesenggiri: Modal budaya dan strategi identitas ulun Lampung. Makara, Sosial Humaniora, 140-150. https://doi.org/10.7454/mssh.v15i2.1420

Mahfud, M. (2018). Tradisi Rasol dalam Perspektif Islam: Studi Etnografis tentang Kearifan Budaya Lokal Masyarakat Buloar Bawean. INTAJ: Jurnal Penelitian Ilmiah, 2(1), 1-44. https:// doi.org/10.35897/intaj.v2i01.113

Marzuki, M. (2014). Tradisi Meugang dalam Masyarakat Aceh: Sebuah Tafsir Agama dalam Budaya. el Harakah: Jurnal Budaya Islam, 16(2), 216-233. https:// doi.org/10.18860/el.v16i2.2781

Napsiah, N., Darmiyati, Z., Ustadi, A., \& Masdjuri, M. (2019). Relasi Sosial Suku Pendatang dan Penduduk Lokal di Lampung Selatan. Jakarta: RajaGrafindo.

Nuha, U. (2016). Ritual Tradition Buka Luwur (A Media Islamic Values and Social Values in The Kudus Society). Jurnal SMART (Studi Masyarakat, Religi, dan Tradisi), 2(01), 55-65. https:/ / doi.org/10.18784/smart.v2i01.298

Nursalikah, A. (2018, 5 18). Rakyat Mesir Ramai-Ramai Beli Lentera Sambut Ramadhan. Retrieved from republika.co.id: https://republika.co.id/berita/ramadhan/tradisiramadhan/18/05/17/p8vpu0366-rakyat-mesir-ramairamai-beli-lentera-sambut-ramadhan Patton, M. Q. (2009). Metode Evaluasi Kualitatif. (B. P. Priyadi, Trans.) Yogyakarta: Pustaka Pelajar.

Riyadi, A. (2017). Kearifan Lokal Tradisi Nyadran Lintas Agama Di Desa Kayen-Juwangi Kabupaten Boyolali. Jurnal SMART (Studi Masyarakat, Religi, dan Tradisi), 3(2), 139-154. https:/ / doi.org/10.18784/smart.v3i2.486

Syahputra, C. M. (2017). Napaktilas Jejak Islam Lampung. Yogyakarta: Global Press.

Setiyawan, A. (2012). Budaya Lokal dalam Perspektif Agama: Legitimasi Hukum Adat ('Urf) dalam Islam. Esensia: Jurnal Ilmu-Ilmu Ushuluddin, 13(2), 203-222. https://doi.org/10.14421/esensia.v13i2.738

Sihaloho, A. (2019, 7 4). Multietnis-Agama di Bakauheni Lampung Selatan Hidup Berdampingan. Retrieved from duajurai.co: http://duajurai.co/2019/07/04/multietnisagama-di-bakauheni-lampung-selatan-hidup-berdampingan/

Sinaga, R. M. (2014). Revitalisasi tradisi: Strategi mengubah stigma Kajian piil pesenggiri dalam budaya lampung. Masyarakat Indonesia (Jurnal Ilmu-Ilmu Sosial Indonesia), 40(1), 109-126. https:/ / doi.org/10.14203/jmi.v40i1.109

Utami, A., \& Astuti, P. (2014). Resolusi Konflik Antar Etnis Kabupaten Lampung Selatan (Studi Kasus: Konflik Suku Bali Desa Balinuraga dan Suku Lampung Desa Agom Kabupaten Lampung Selatan). Journal of Politic and Government Studies, 3(2), 126-135. https://ejournal3.undip.ac.id/index.php/jpgs/article/view/4999

Yasinta, V. (2018, 5 23). Permainan Tradisional "Mheibes" Meriahkan Ramadhan di Irak. (V. Yasinta,
Ed.)
Retrieved
from
kompas.com:

Copyright (C) 2020. Owned by Author(s), published by Society. This is an open-access article under the CC-BY-NC-SA license. 
https:/ / internasional.kompas.com/read/2018/05/23/17195041/permainan-tradisionalmheibes-meriahkan-ramadhan-di-irak?page=all

\section{About the Author}

Napsiah, obtained her Doctoral Degree from Padjadjaran University, Bandung, Indonesia, in 2015. The author is an associate professor at the Department of Sociology, Faculty of Social Sciences and Humanities, Sunan Kalijaga State Islamic University of Yogyakarta, Indonesia. E-Mail: napsiah@uin-suka.ac.id 